总学雑. (J. Japan. Soc. Hort. Sci.) 60 (4) : 997-1002. 1992.

\title{
胚培養によるテッポウユリ，シンテッポウユリとオトメユリ， ササユリの種間雑種
}

\author{
凧崎桂一・馬田雄史・浦島 修・川田穣一* \\ 国重正昭**.村上欣治 \\ 富山県宸業技術センター野菜花き試験場９39-13 富山県䂯波市五郎丸
}

\begin{abstract}
Interspecific Hybrids of Lilium longiflorum and L. $\times$ formolongi with $L$, rubellum and L. japonicum through Embryo Culture
\end{abstract}

Keiichi Okazaki, Yuji Umada, Osamu Urashima, Joichi Kawada, Masaaki Kunishige and Kinji Murakami

Toyama Veg. Orna. Crop Res. Sta., Goromaru, Tonami, Toyama 939-13

\begin{abstract}
Summary
To develop pink Easter lilies through interspecific hybridization, Lilium longiflorum and $L . \times$ formolongi were crossed with $L$. rubellum and $L$. japonicum.

1. Interspecific hybrids between $L$. longiflorum $\times L$. rubellum, $L . \times$ formolongi $\times L$. rubellum, and $L . \times$ formolongi $\times L$. japonicum were obtained by pollinating the cut surface of styles (stylecutting method) and culturing the resulting embryo in vitro. Progenies of the respective crosses were pink, pale pink, and white.

2. Of the two cultivars and two selections of $L$. longiflorum employed as the mother parent, the largest number of ovaries and the most embryos per ovary were found in 'Georgia' pollinated with pollen from $L$. rubellum.

3. The percentages of developed ovaries of $L . \times$ formolongi pollinated with pollen from $L$. rubellum or pollen of $L$. japonicum were higher than when $L$. longiflorum was used as the mother parent.

4. The $\%$ fertility of pollen from interspecific hybrids was low with the exception of pollen from a hybrid between $L . \times$ formolongi and $L$. nubellum which attained $95.2 \%$. This high rate of pollen fertility in this hybrid is attributed to its amphidiploid $(2 n=48)$ nature.

5 . Hybrids progenies between $L . \times$ formolong $i$ and $L$. rubellum produced viable embryos when they were back-crossed with $L$. rubellum, but not when they were triple-crossed with L. longiflorum.
\end{abstract}

\begin{abstract}
緒 言
テッポウユリはュリ類の中では球根生産が容易であ ク，切り花の周年生産が可能であることから，球根・ 切花生産においてともに重要な花きの一つである。し かし，花色が白のみに限られ，切り花としての利用箱 囲が限られるという問題があるため，多㥞な花色を持 つテッポウユリの筲成が望まれている。
\end{abstract}

1991年 5 月20日 受理.

*現在：全国隹業協同組合速合会.

**現在：揹水省野菜茶業試歌場。
種内に花色変異個体を持たないテッポウユリでは, 近縁種から花色遣伝子を導入する必要があるが、テッ ポウユリの近緑種で有色花を持つスカシュリ，カノコ ユリ，オトメユリ，ササユリ等の種を用いて，通常の 柱頭受粉によりテッポウュリとの種間交熦個体を得る ことは極好困難であった（1，7)．しかし，近年， 花柱切断法と肧培養を組み合わせることによって,テッ ポウユリと交雑可能な種の組合せが著しく增加した（1， 3，10).テッポウュリにアントシアニン系色素を導入 する種としては，比較的交雑し易いスカシュリについ 
て報告が多く(3，4，6，9)，これらの雑種の一つとし でロートホルン'が栽培されている。一方，オトメユリ との交雑によっても有色花のテッポウユリ型雑種が得 られているが(8，9)，ササユリとの交㔞は報告例が ない，以上のように，テッポウュリの種間交雑は限ら れた種間の組合せで行われており，有色花テッポウュ リ育成の試みはまさに緒についたところといえる。

ここでは，テッポウユリとの交雑が比較的困難なオ トメュリ，ササュリをテッポウュリに交雑し，アント シアニン系花色のテッポウユリへの導入を図ったとこ ろ，目的とした雑種を得ることができたので報告する。

\section{材料および方法}

子房親として，鹿児島県農業試軻場花き部より詨与 されたテッポウュリ(Lilium longiflorum Thunb.) 2 系統 (庇系 100 系統，K37-25-12)のほか, テッポウユ リ 2 品種(ジョージア, Uのもと), シンテッポウユリ

(L. $\times$ formolongi) 1 品種（銀河一号）を用い, 花 粉親としてササユリ (L. japonicum Thunb.)，オトメ ユリ（L. rubellum Baker）を用いた。交配は花柱切 断法によって行い（1），雑種胚は交配しておよそ40日 後の朝果が黄化裂開する直前に摘出し, MS 培地上で培 䓹した（2）。

雑種の花粉稳性の検定は, 酢酸カーミンで花粉を染 色した時，均一に染色された，棈円形のものを稔性花 粉とし，染色が部分的で不充分なものや内容物がない ため溑れた花粉は不稔性花粉とした。

杂倠種の染色体数は, 根端組織を $0.1 \%$ コルヒチン水溶 液に $3 \sim 4$ 時間浸清後, 眽酸アルコール（1：3）で 固定し, 酰酸カーミン染色後押し瀆して観察した.

雑種のパーオキシダーゼアイソザイムは，葉の先端 部を $0.2 \mathrm{mg}$ 取り, $1 \mathrm{ml}$ の $0.01 \mathrm{M}$ リン酸緩衝液 $\mathrm{pH}$
7.0 中で磨研し $10,000 \mathrm{~g}$ で15分間遠心分離した後, 上 澄液を用いて等電点電気泳動で分析した，等電点電気 泳動は, $1 \mathrm{~mm}$ 厚の水平型ポリアクリルアミドゲル (AMPHOLINE PAGPLATE, pH 3.5-9.5, LKB 社) を用い, $1 \mathrm{w} \cdot \mathrm{cm}^{-1} て ゙ 30$ 分間子備泳動した後, ゲル上 に抽出液を滴下し, さらに 90 分間電気泳動した。電気 泳動が終了したダルは，0.05\%の3,3’ジアミノベンジ ジンと $0.05 \%$ の過酸化水素を含む $50 \mathrm{mM}$ トリス・塭酸 緩衝液 $\mathrm{pH} 8.0$ で発色させた。

\section{結果および考察}

花柱切断法を用いたテッポウユリとオトメユリとの 種間交雑では，子房親に゙ジョージア’, 鹿系 100 系統, ‘ひのもと', K 37-25-12 系統を用いたが，結実率はをれ ぞれ 16.4，15.0，3.4，0\%であり，1荻当たりの雑種 胚数はそれぞれ 7.4，2.5，1.0，0個であった。雑種胚 の長さは大部分 $0.2 \mathrm{~mm}$ 前後であったが, ‘ジョージア’

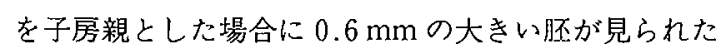

(第 1 表).このように子房親に用いた品種によって交 雑親和性に差が見られ,供試した品種の中では, ‘ジョー ジア’の結実率が最も高く，1荻当たりの雑種胚数も多 く，オトメユリとの交雑親和性が岁いと思われた。

シンテッポウユリとオトメュリの交雑では，結実率 は $52.9 \%$ であり，テッポウユリメオトメユリの交雑と 比べて高かった．また，肧の大きさは $0.3 \sim 3.0 \mathrm{~mm}$ あり，テッポウユリとの交雑と比べて大きかった（第 1 表)．シンテッポウュリとササユリの交雑では， 51. $4 \%$ 結実率が高かっっが(第 2 表)，テッポウュリと ササュリの種間交雑では結実しなかった。このように シンテッポウユリとオトメユリあるいはササュリとの 交雑では，交雑率は極めて高かったが，これらの雑種 $F_{1}$ の一部に，傾母個体々思われる個体が見られた。傾

Table 1. Interspecific hybridization of Lilium longiflorum and L. $\times$ formolongi crossed with L. mubellum by cut-style pollination.

\begin{tabular}{|c|c|c|c|c|c|c|}
\hline Cross combination & $\begin{array}{c}\text { No. of flowers } \\
\text { pollinated }\end{array}$ & $\begin{array}{l}\text { No. of ovaries } \\
\text { developed (\%) }\end{array}$ & $\begin{array}{l}\text { No. of ovaries } \\
\text { observed }^{2}\end{array}$ & No. of embryos & $\begin{array}{c}\text { No. of embryos } \\
\text { per ovary }\end{array}$ & $\begin{array}{c}\text { Length of } \\
\text { embryos }(\mathrm{mm})\end{array}$ \\
\hline \multicolumn{7}{|c|}{ L. longiflorum $\times$ L. rubellum } \\
\hline 'Georgia'y & 61 & $10(16.4)$ & 9 & 67 & 7.4 & $0.2 \sim 0.6$ \\
\hline Ka 100 & 20 & $3(15.0)$ & 2 & 5 & 2.5 & 0.2 \\
\hline 'Hinomoto' & 29 & $1(3.4)$ & 1 & 1 & 1.0 & 0.2 \\
\hline K37-25-12 & 22 & $0(0)$ & - & - & - & - \\
\hline \multicolumn{7}{|l|}{$L . \times$ formolongt $\times$ $\times$. } \\
\hline nubellum & 17 & $9(52.9)$ & 6 & 39 & 6.5 & $0.3 \sim 3.0$ \\
\hline
\end{tabular}

"From this item (No. of ovaries), the evaluation for 3 items of right hand was done.

$y$ cv. Ginga No. 1 .

${ }^{x}$ These are cv. or strain of $L$. longiflorum. 
母個体の出現率については, 球根苝成中の未開花球が あり正碓な数は示せないが，得られた杂隹種のうち約半 数が傾坶個体で，オトメユリよりササュリとの交雑の 場合に傾母個体が多かった。したがって，結実率が高 かったのは単為生殖のためか，あるいは自殖によるも のと思われ，交雑率についてはさらに検討を要する。 しかし、シンテッポウュリを母本とした交配では,テッ ポウユリの交雑では青成できなかったササユリとの柾 種が得られていることも考え合わせると，やはり， シ ンテッポウユリはテッポウユリよりササュリ，才トメ ユリに対して交雑親和性が高いと考えられた。また， その理由の一つとして，シンテッポウュリは種間交雑 によって育成されな执か奉生系品種であるため（7)， その遗伝的背景がへテロであり，ササュリ，オトメュ リの種間交雑において多㥞な遗伝子糬成を持つ雑種胚 が得られ，雑種顺の生存率が问上したことが考えられ る.

胚培整の結果を第 3 表に示したが，テッポウュリで は“ジョージア’メオトメユリ，鹿系 100 系統メオトメ ユリ, ‘Uのもと’メオトメコリの雑種胚を培䗒し, 生存 率はそれぞれ 14.9,9.5，0\%であり，極めて低かった。 シンテッポウユリでは, ‘銀河一号’メオトメユリ, ‘銀河
一号’メササュで雑種が得られ, 生存率はそれぞれ 30 . 8\%, 55.3\%であったが, 生存率が高かったのは前述し たように傾母個体が含まれていたためと思われる。今 後, 微小肧の培罂法や傾母個体発生の防止法を検討子 る必要があると思われた。

育成した雑種は，それぞれの交配組合わせで数個体 ずつ開花に至っているが，各交配組合せの典型的な個 体の特性を第 4 表に示した，植え付けた球根サイズが 一定でないため正確な比較はできないが, ‘ジョージア’メ オトメユリの雑種は花数 3 輪でおよそ $46.0 \mathrm{~cm}$ の草丈 で(第 1 図-A)，鹿系 100 系統メオトメユリの雑種は 2 輪で草丈 $48.5 \mathrm{~cm}$ であり（第 1 図-B)，较本に用いたテッ ポウユリ'ジョージア゙に比べて矮性となった. ‘銀河一号’ オトメュリの草丈は $84.5 \mathrm{~cm}$ (第 1 図-C), ‘銀河一号’ ササュリの草丈は $98.5 \mathrm{~cm}$ であり(第 1 図-D), テッポ ウユリより高かった，四つの雑種いずれもが，花の大 きさや花容は，テッポウユリとオトメュリの中間であ ク，テッポウユリほど花被の基部がラッパ状になって いなかった. ‘銀河一号’メササュリの花は, 他の雑種に 比べるとやや大輪であった，全雑種とも葉数はオトメ ユリよりは多く，テッポウュリよりは少なく，葉先は 垂れる傾向にあった。花色は, 鹿系 $100 \times$ オメメリの

Table 2. Interspecific hybridization of $L$. longiflonm and $L . \times$ formolongi crossed with $L$. japonicum by cut-style pollination.

\begin{tabular}{|c|c|c|c|c|c|c|}
\hline Cross combination & $\begin{array}{c}\text { No. of flowers } \\
\text { pollinated }\end{array}$ & $\begin{array}{l}\text { No. of ovaries } \\
\text { developed }(\%)\end{array}$ & $\begin{array}{c}\text { No. of ovaries } \\
\text { observed }\end{array}$ & No. of embryos & $\begin{array}{c}\text { No. of embryos } \\
\text { per ovary }\end{array}$ & $\begin{array}{c}\text { Length of } \\
\text { embryos ( } \mathrm{mm} \text { ) }\end{array}$ \\
\hline \multicolumn{7}{|l|}{ L. longiflorum $\times L$. } \\
\hline \multicolumn{7}{|l|}{ japonicum } \\
\hline 'Geogia' & 53 & $0(0)$ & - & - & - & - \\
\hline Ka 100 & 16 & $0(0)$ & - & - & - & - \\
\hline 'Hinomoto' & 36 & $0(0)$ & - & - & - & - \\
\hline $\mathrm{K} 37-25-12$ & 40 & $0(0)$ & - & - & - & - \\
\hline \multicolumn{7}{|l|}{$L . \times$ formolong $i^{2} \times L$. } \\
\hline japonicum & 37 & $19(51.4)$ & 19 & 48 & 2.5 & $0.3 \sim 1.5$ \\
\hline
\end{tabular}

cv. Ginga No. 1.

Table 3. Results from embryo culture in interspecific hybridization.

\begin{tabular}{lcc}
\hline \hline Cross combination & $\begin{array}{c}\text { No. of embryo } \\
\text { cultured }\end{array}$ & $\begin{array}{c}\text { No. of seedlings } \\
\text { obtained (\%) }\end{array}$ \\
\hline L. longiflonum $\times$ L. rubellum & & $10(14.9)$ \\
'Georgia' & 67 & $2(9.5)$ \\
Ka 100 & 21 & $0(0)$ \\
'Hinomoto' & 1 & $12(30.8)$ \\
L. $\times$ formolongi ${ }^{2} \times$ L. rubellum & 39 & $21(55.3)$ \\
L. $\times$ formolongi ${ }^{z} \times$ L. japonicum & 38 & \\
\hline
\end{tabular}

${ }^{z}$ cv. Ginga No. 1 . 

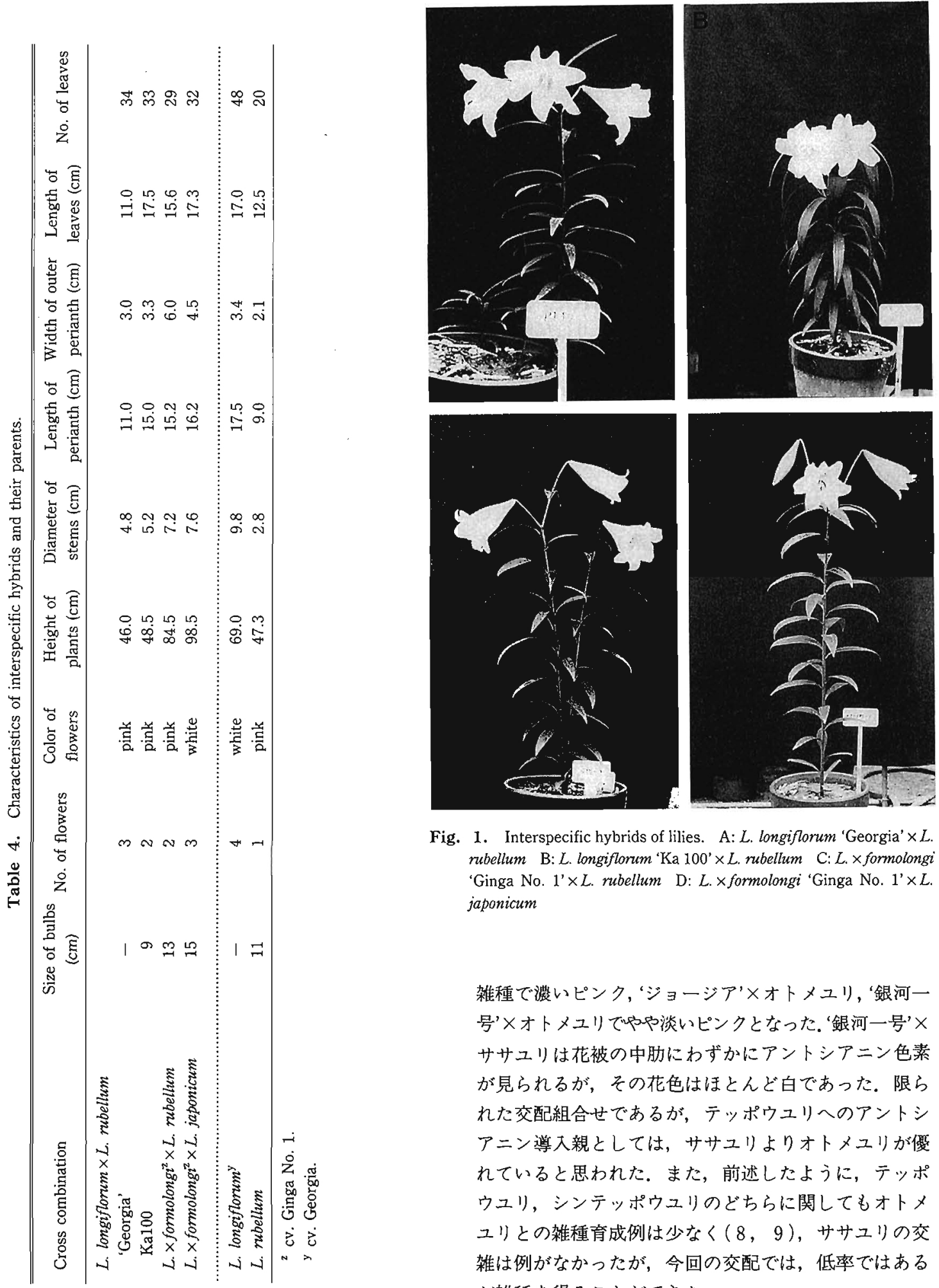

Fig. 1. Interspecific hybrids of lilies. A: L. longiflonum 'Georgia' $\times L$. nebellum B: $L$. longiflonum 'Ka 100 ' $\times$ L. nubellum C: $L . \times$ formolongi 'Ginga No. 1 ' $\times L$. rubellum D: $L . \times$ formolongi 'Ginga No. 1 ' $\times L$. japonicum

森種で濃いピンク, ‘ジョージア’メオトメユリ, ‘銀河一 号’メオトメユリでやや淡いピンクとなった。銀河一号’× ササユリは花被の中胁にわずかにアントシアニン色素 が見られるが，その花色はほとんど白であった。限ら れた交配組合せであるが，テッポウュリへのアントシ アニン導入親としては，ササユリよりオトメユリが倀 れていると思われた。 また，前述したように，テッポ ウユリ，シンテッポウュリのどちらに関してもオトメ ユリとの雑種育成例は少なく（8，9），ササュリの交 嵙は例がなかったが，今回の交配では，低率ではある が雑種を得ることができた。 
テッポウユリとオトメュリの雑種では，開花当日は 筒状花になっているが, 開花後日数がたつと花被の基 部が分離する場合が多かった(第 2 図).シンテッポウ ユリではこの傾向は少なかった，交雑親和性の面ばか クでなく，花被の基部が分離しない雑種の巟成という 面でも，シンテッポウユリがテッポウユリより交雑親 として優れていると思われた。

‘銀河一号’とオトメコリの雑種のパーオキシダーゼア イソザイムを調查したところ，雑種はシンテッポウユ リのバンドのほか，オトメュリのバンドを数本持って おりアイソザイムからも雑種性が明らかになった（第 3 図).

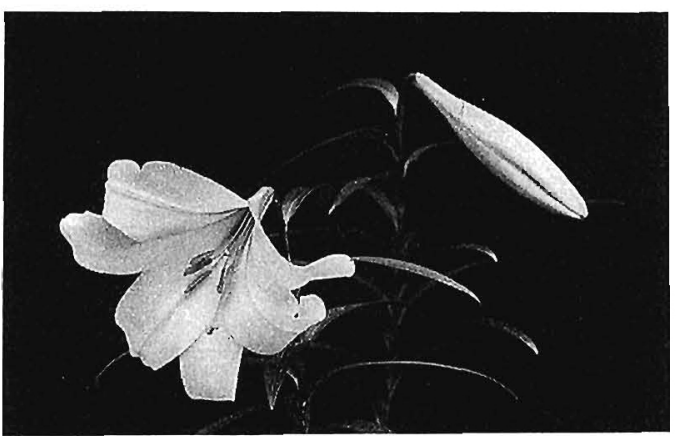

Fig. 2. The perianth separate in the base of flower in the hybrids of $L$. longiflorum 'Ka $100^{\prime} \times L$. rubellum.

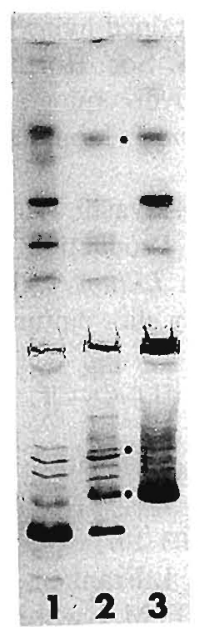

Fig. 3. Isozyme patterns of peroxidase in $L . \times$ formolongi 'Ginga No. 1' (1); $L . \times$ formolongi 'Ginga No. 1 ' $\times L$. rubellum (2) and L. rubellum (3) using thin-layer polyacrylamide gel isoelectrofocusing. Dots indicate the bands that were transmitted from the pollen parent $(L$. rubellum) to the hybrid progeny.
雑種の花粉稔性を調查したところ，大部分の個体で 低い花粉稔性を示したが，シンテッポウユリメオトメ ユリの雑種の中で, 95.2\%と高い稔性を持つ個体があっ

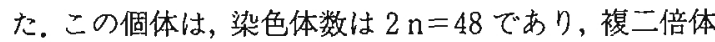
であった(第 5 表). 複二倍体の生起ステージとしては,

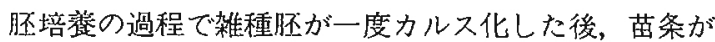
再分化してくる場合があるので，この過程で自然倍化 したのか，あるいは，その後の球根蒜成の段階で倍化 したことも考えられる。いずれにしても，複二倍体雑 種が离稔性を持つことは，浅野（5）の報告と一致し た.

一方，種間稚種にオトメユリの花粉（一部オトメユ リの雑種花粉）とテッポウユリの花粉を交配したとこ ろ，前者の交配では脴が得られたが，後者の交配では 肧が得られなかった(第 6 表)。このような種間雑種に 对する交配において，雑種育成に用いた子房親より花 粉親の花粉を用いて交配した場合に種子ができやすい 傾向は，浅野（4）功報告している，有色花のテッポ ウユリを䏍成するためには雑種にテッポウュリを交雑 し，花色を維持しつつ草准をテッポウュリに近づける 必要があるが，今回の雑種との效実験ではテッポウ ユリの交雑はできなかったことから，今後，高稔性の 複二倍体雑種を用いた交雑の検討が必要である。

\section{摘 要}

アントシアニン系花色のテッポウユリの育成を目的 として，子房親としてテッポウユリおよびシンテッポ ウユリと花粉親としてオトメユリおよびササュリとの それぞれの種間䧱種の育成を試みた。

1. 胚培荃法と花柱切断受粉法を用いることによって テッポウュリメオトメュリ，シンテッポウユリメオト メユリ，シンテッポウュリメササュリの組合せで種間 雑種が得られた。花色は，テッポウユリメオトメュリ の雑種が㴗いピンク，シンテッポウユリメオトメユリ はやや淡いピンクとなった。シンテッポウユリメササ ユリの雑種は白花であった。

2.テッポウユリメオトメユリの交雑ではテッポウュ リ 2 品種，2系統を用いたが，結実率に品種間差が見 られ、“ジョージア’の結実率が最も高かった。

3. シンテッポウユリは,テッポウユリに比べオトメ ユリ，ササュリとの交雑した時は高率で結実した。

4. 種間雑種の花粉稔性は, 大部分の個体で低かった が, シンテッポウュリメオトメユリの雑種の中で, 95. $2 \%$ と高い花粉稔性を持つ個体があった.この個体の染 色体数は $2 n=48$ であり，この高花粉稔性は, 複二倍体 
Table 5. Chromosome number and pollen fertilities in interspecific hybrids.

\begin{tabular}{|c|c|c|c|}
\hline Cross combination & Strain No. & Fertility (\%) & $\begin{array}{l}\text { Chromosome } \\
\text { number ( } 2 \text { ) }\end{array}$ \\
\hline \multirow{2}{*}{$L . \times$ formolongt ${ }^{2} \times L$. japonicum } & 1 & 0 & 24 \\
\hline & 12 & 1.3 & - \\
\hline \multirow[t]{3}{*}{ L. longiflorum ${ }^{\mathrm{y}} \times$ L. rubellum } & 1 & 12.2 & - \\
\hline & 1 & 0 & 24 \\
\hline & 2 & 0 & - \\
\hline \multirow[t]{3}{*}{ L. $\times$ formolongt $t^{z} \times$ L. rubellum } & 3 & 95.2 & 48 \\
\hline & 4 & 10.7 & - \\
\hline & 5 & 5.0 & - \\
\hline
\end{tabular}

cv. Ginga No, 1

${ }^{y}$ cv. Ka100.

Table 6. The backcrosses or triple-crosses of interspecific hybrids by cut-style pollination.

\begin{tabular}{|c|c|c|c|c|}
\hline Cross combination & & $\begin{array}{c}\text { No. of flowers } \\
\text { pollinated }\end{array}$ & $\begin{array}{c}\text { No. of ovaries } \\
\text { developed }\end{array}$ & No. of embryos \\
\hline \multirow{2}{*}{ (L. longiflonum ${ }^{y} \times$ L. rubellum $) \times$} & L. longiflorum ${ }^{\mathrm{x}}$ & 10 & 0 & - \\
\hline & L. nubellum & 15 & 0 & - \\
\hline \multirow{2}{*}{$\left(\right.$ L. $\times$ formolong $z^{2} \times$ L. rubellum $) \times$} & L. longiflorum & 10 & 0 & - \\
\hline & L. rubellum & 18 & 18 & 5 \\
\hline \multirow{2}{*}{$\left(L . \times\right.$ formolongi $i^{2} \times L$. japonicum $) \times$} & L. longiflonum & 3 & 0 & - \\
\hline & ' (a seedling of $\times$ Oriental hybrids) & 2 & 2 & 3 \\
\hline
\end{tabular}

"cv. Ginga No. 1.

${ }^{y}$ cv. Ka 100.

${ }^{x}$ cv. Georgia.

植物の特性によるものである。

5. 種間雑種に,オトメユリとテッポウユリの花粉を 交配したところ，前者の交配では胚が得られたが，後 者の交配では怌が得られなかった。

謝辞 本稿を草するにあたり，元笼水省脤業生 物資源研究所所長, 現全宸営脤対策部の鳥山国士博士, 富山目宸業技術センター野菜花き試臥場場長の梅原吉 㢇博士にご校閲载いた。ここに記して感謝の意を表す る.

\section{引用文献}

1. 浅野義人・明道 博. 1977. ユリの遠緑種間交雑に 関する研究。(第 1 報)。花柱切断授粉法による交 配。图学雑. 46:59-65.

2. 浅野㼁人・明道 博. 1977。.ユリの遠緑種間交雑に

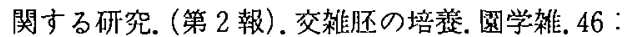
267-273.

3. 浅野莪人・明道 博. 1978. ユリの遠縁種間交雑に 関する研究. (第 3 報)。胚培羡により作出された遠 縁種間雑種について。图学雑，47：401-414。

4. Asano, Y. 1980. Studies on crosses between distantly related species of lilies. V. Characteristics of newly obtained hybrids through embryo culture. J. Japan. Soc. Hort. Sci. 49 : 241-250.

5. Asano, Y. 1982. Overcoming interspecific hybrid sterility in Lilium. J. Japan. Soc. Hort. Sci. 51 : 75-81.

6. Kanoh, K., M. Hayashi, Y. Serizawa and T. Konishi. 1988. Production of interspecific hybrids between Lilium longiflonum and $L . X$ elegance by ovary slice culture. Japan. J. Breed. $38: 278-282$

7. 清水基夫．1971，日本のユリ，p.245-247，誠文堂 新光社.

8. 滰沢久筧. 1989. ユリ類育種の現状と問題点. 2. 新 品種の育成経過と特性. 日種協育技術研究会シン ポジウム凟料。 103-107.

9. van Tuyl, J. M., J. Franken, R.C. Jongerius, A. M. Lock and T. P. M. Kwakkenbos. 1986. Interspecific hybridization in Lilizm. Acta Hort. 177 : 591-595.

10. Watts, V. M. 1967. Influence of interstylar pollination seed set in lilies. Proc. Amer. Soc. Hort. Sci. $91: 660-663$. 